\title{
Using organic amendments to improve productivity of cucumber plants grown under sandy substrate culture
}

\author{
Abo Sedera, F. A 1, S.M. Eid' ${ }^{1}$ L.A. Badr'1 M. S. A. Emam² and A. M.H. Hawash². \\ 1- Hort. Dept. Fac. Agric, Moshtohor. Benha University. \\ 2- Closed Agricultural Methods Research Dept., Central Laboratory for Agriculture Climate, Agriculture \\ Research Center \\ Corresponding author: hawash_hawash78@yahoo.com
}

\begin{abstract}
Two experiments were carried out at Central Laboratory for Agriculture Climate (CLAC), Agriculture Research Centre, Egypt during the two successive spring seasons of 2012 and 2013 under unheated double span plastic house $(18 \times 60 \times 3.2 \mathrm{~m})$, to study the ability of improving sand culture via organic amendments cucumber production (Cucumis sativus L. cv. Dp164 F1). Three different fertigation types (nutrient solution, compost tea and vermi- liquid) combined with three levels of commercial compost and vermicompost mixed with sand as a substrate culture at 10, 20 and $30 \%$ in addition to the control treatment (100\% sand) were performed. Plant height, number of leaves, leaves area; chlorophyll reading, total yield, N, P and K content in leaves of cucumber were measured at 90 days during the growth season of cucumber. Obtained results of the effect of nutrient solution sources indicated that the chemical nutrient solution recorded the highest vegetative growth traits and yield characteristics. In addition, results indicated that increasing commercial compost and vermicompost rate from 0 to $20 \%$ had positive significant effects on vegetative growth, yield and macro nutrient content of cucumber plant, while increasing the rate up to $30 \%$ had no subsequent improving effect. Sand + vermicompost (80:20 v/v) followed by sand + vermicompost (70:30 v/v) recorded the highest values of the vegetative growth characteristics during the two seasons compared to other treatments. Sand + vermicompost $(80: 20 \mathrm{v} / \mathrm{v})$ combined with chemical nutrient solution had the highest values of early and total yield $\left(\mathrm{kg} / \mathrm{m}^{2}\right)$.
\end{abstract}

Keywords: Vermicompost, Vermi-Liquid, Compost tea, Nutrient solution, Sand culture, Vegetative growth, Yield, Macro nutrient content and cucumber.

\section{Introduction}

Cucumber is one of the major vegetable crops grown in Egypt under plastic house conditions. It is subtropical vegetable crop that grows successfully inside plastic houses under conditions of high light, humidity, moisture, temperature and fertilizers (ElAidy, 1990, and Abul-soud, 2005).

Sand is the oldest hydroponic media, it is heavy when wet and tends to dry out quickly. It provides excellent support, gas exchange but has insufficient water and nutrient supplying capacity. The coarse particles of sand have little surface area per unit of volume compared to the finer particles of soil or peat moss. Since water is held on the surfaces of particles, sand has a small water holding capacity. Plants grown in sand would need to be watered three or more times per day especially in the summer. Since most nutrients in a sand medium are held in the water films, there is likewise little nutrient reserve. The difference between the sand and gravel is purely one of particle size. (Abul-soud, 2005).

Compost is an organic residual which gradually decomposes in the soil after application and thus has fertility extension for a long time. It is very effective in supplying the important plant nutrients and trace elements which the crop plants need during their growth to maintain the productivity of the land (Tsiang, 1963).

Compost tea is a brew favored by many organic growers. It's made by adding small amounts of mature compost to unheated water and leaving it to sit, or steep. The compost tea is applied as a foliar spray or soil drench to promote plant growth and suppress microbes (Sharon, 2006). Compost tea, as a liquid extract of humic compost containing large numbers of beneficial microorganisms. It is already used in many nurseries in Europe as an aid to pest and diseases management in plant production (Summers, 2006).In this respect, Hggag and Saber (2007) mentioned that compost tea have beneficial effects on crops such as crop disease suppression, root growth stimulation, and higher increase of yield with higher quality. However, Abou-El-Hassan et al. (2008) reported that applying compost tea as organic nutrient solution for cantaloupe plants grown in nutrient film technique reduced plant growth expressed as plant length, stem diameter, number of leaves and leaf area compared with inorganic nutrient solution.

Al-Redhaiman et al. (2005) investigated the influence of different nutrient sources (inorganic source and chicken manure, rabbit manure extracts as a natural organic source in addition to Al-Bostan 
liquid solution as an artificial organic fertilizer source.) on mineral accumulation and growth of lettuce plants under hydroponic condition. They noticed that the highest fresh and dry weight of lettuce head was observed with inorganic fertilizer solution followed by rabbit manure extract followed by Al-Bostan liquid solution. On the contrary, the lowest values were recorded with chicken manure extract.

Vermicomposting has been discussed as a key step in sustainable Organic Solid Wastes (OSW) management, in many countries like Germany (Ernst et al., 2008), USA (Arancon et al., 2008), Spain (Monroy et al., 2009), China (Li., 2009), India (Ghosh C. 2004) and Vietnam (Yadav et al., 2010). Vermicompost is a nutrient-rich, microbiologicallyactive organic amendment that results from the interactions between earthworms and microorganisms during the breakdown of the use of vermicompost in sustainable agriculture organic matter. It is a stabilized, finely divided peat-like material with a low $\mathrm{C}$ : $\mathrm{N}$ ratio, high porosity and high water-holding capacity, in which most nutrients are present in forms that are readily taken up by plants (Domínguez, 2004).Vermicompost could be used as a natural fertilizer having a number of advantages over chemical fertilizers, possibly due to better physical properties, higher microbial and enzymatic activity and higher content of available nutrients. Producers accept vermicompostis greater than that of compost (Abul-Soudet al., 2014).Atiyehet al (2002) further speculate that the growth responses observed may be due to hormonelike activity associated with the high levels of humic acids and humates in vermicomposts: there seems a strong possibility that plant growth regulators which are relatively transient may become adsorbed on to humates and act in conjunction with them to influence plant growth.Vermicompost increase the nutritional quality of some vegetable crops such as tomatoes (Gutiérrez-Miceliet al., 2007), spinach (Peyvastet al., 2008), strawberries (Singh et al., 2008), and lettuce (CoriaCayupán et al., 2009)and Chinese cabbage (Wang et al., 2010).

Atiyeh et al. (2000) found that compost was higher in ammonium, while vermicompost tended to be higher in nitrates, which is the more plant-available form of nitrogen. Similarly, work at NSAC by Hammermeisteret al. (2004) indicated that "Vermicomposted manure has higher $\mathrm{N}$ availability than conventionally composted manure on a weight basis". The latter study also showed that the supply rate of several nutrients, including $\mathrm{P}, \mathrm{K}, \mathrm{S}$ and $\mathrm{Mg}$, were increased by vermicomposting as compared with conventional composting. These results are to some extent typical of what other researchers have found (Short et al., 1999 and Sudha and Kapoor, 2000). Using vermicompost as a substrate amendment in sand culture $(20: 80 \mathrm{v} / \mathrm{v})$ improve the vegetative growth characteristics, early and total yield $/ \mathrm{m}^{2}$ of snap bean combined with chemical nutrient solution compared with other nutrient solution (AboSederaet al ,2015)

The aim of this experiment is to determine the best level of mixture from compost and vermicompost with sand culture to improve physical and chemical properties of sand culture and inturn enhance the vegetative growth and productivity of cucumber plants under protected cultivation system.

\section{Material and Methods}

The current study was carried on to investigate the possibility of using vermicompost as an organic substrate and vermi-liquid as a nutrient solution for producing cucumber in sand culture under protected cultivation.

These experiments were practiced in Central Laboratory for Agriculture Climate (CLAC), Agriculture Research Center, Ministry of Agriculture, Egypt, during the two successive spring seasons of 2012 and 2013 under unheated double span plastic house $(18 \times 60 \times 4.5 \mathrm{~m})$ and the cultivated experiment area was $9 \times 20 \mathrm{~m}$.

\section{Plant material:}

Cucumber (Cucumis sativus L.), cv. DP 164 F1 (dp elite zaden, Holland) was used in this study. Seeds were sown on 5/1/2012 and 3/1/2013 in foam trays containing peat moss mixed with vermiculite $(1: 1$ $\mathrm{v} / \mathrm{v}$ ) and transplanted on 10/2/2012 and 15/2/2013 in the two growing seasons, respectively. The growing pots $(25 \mathrm{~cm}$ diameter $\times 30 \mathrm{~cm}$ length) filled with different sand mixtures. One seedling was planted in each pot. Pots were placed in double rows. The final plant spacing was $50 \mathrm{~cm}$ in the row, $40 \mathrm{~cm}$ between the rows, and $90 \mathrm{~cm}$ in between the double rows.

\section{The vermicomposting process:}

Epigiec earthworms imported from Australia, Lumbriscusrubellus (Red Worm), Eiseniafetida (Tiger Worm), Perionyxexcavatus (Indian Blue) and Eudriluseugeniae (African Night Crawler) were used in the vermicomposting beds system under this study. According to Ernst et al., (2008), Abul-Soud et al. (2009) and Venugopalet al. (2010) five $\mathrm{kg}$ of epigiec earthworms were taken and placed in each bed system. Worm diameter: $0.5-5 \mathrm{~mm}$ and worm length: $10-120 \mathrm{~mm}$. Bed system of vermicomposting was used in this investigation for producing the vermicompost and vermi-liquid. Eight Beds were established under black net house by digging the soil and mulched with black polyethylene plastic sheet $0.5 \mathrm{~mm}$ to perform a bed with length 2.5 $\mathrm{m}$, width $1.2 \mathrm{~m}$ and depth $50 \mathrm{~cm}$. A slope $1.5 \%$ had been done to collect the vermi-liquid through water bucket. Mixing the different raw materials: cattle manure (C. M) + vegetable and fruit wastes (V. F. W) + shredded paper (Sh. P) in the rate of 2: 2: $1(\mathrm{v} / \mathrm{v})$, respectively was done by using turning machine pre- 
composting of different raw materials for 7 to 10 days before feeding it to worms to avoid the thermophilic stage (increase temperature above $35^{\circ} \mathrm{C}$ cause the death of earthworms in vermicompost systems). After pre-composting done, the final mix soaked in water for $1 / 2$ to 1 hour to make sure it is not drier and put it in lines along the bed. The feeding of earthworm was done every two days and every 21 days the earthworms were fasting for 7 days to give them the opportunities to re-eat the cast and to avoid non composted wastes. Moisture content was in the range of $60-70 \%$.

\section{Study treatments:}

This experiment included 21 treatments resulted from the combination of three nutrient solutions with seven substrate mixtures as follow:-

\section{A- Fertigation sources:}

Three sources of fertigation have been used in this study as follow:

1. Inorganic (chemical) nutrient solution E.C $2.5 \mathrm{ds} / \mathrm{m}$ (check) (El-Behairy, 1994).

2. Compost- tea E.C $2.5 \mathrm{ds} / \mathrm{m}$ (C.T)

3. Vermi-liquid E.C $2.5 \mathrm{ds} / \mathrm{m}$ (V.L)

\section{B- Sand mixtures:}

Seven substrate culture have been used in relation to production of cucumber as follow:

1. Sand $(100 \%)$

2. Sand $90 \%+10 \%$ Compost

3. Sand $80 \%+20 \%$ Compost

4. Sand $70 \%+30 \%$ Compost

5. Sand $90 \%+10 \%$ Vermicompost

6. Sand $80 \%+20 \%$ Vermicompost

7. Sand $70 \%+30 \%$ Vermicompost

The experimental design was a spilt-plot design with 3 replicates. The sources of nutrient solutions were assigned as main plots and substrate amendments rates as subplots.

\section{System materials:}

Plastic pots 81 ( $25 \mathrm{~cm}$ diameter x $30 \mathrm{~cm}$ height) were used, the pots were filled with different substrate mixes and placed in two rows in open substrate system. The pots arranged in two rows per bed. The final plant spacing was $50 \mathrm{~cm}$ in the row, $40 \mathrm{~cm}$ between the rows, and $90 \mathrm{~cm}$ in between the double rows.

Stock nutrient solutions of compost teas were prepared by soaking $4 \mathrm{~L}$ from compost in $20 \mathrm{~L}$ of water (1:5 by volume), the brewing of the compost occurring after 24 hours to get the concentrated compost tea. The concentrated compost tea was filtrated by using nets to get the clear solution, and then used to prepare the nutrient solution by diluting this stock up to 1201 water in solution tank, according to Abou-El-Hassan etal. (2008).

The vermi-liquid was collected through vermicomposting process. The vermi-liquid filtered by using nets to remove any residues or dust that could cause blocking of drippers before diluted to the desire EC.

Different nutrient solutions pumped via submersible pump (110 watt). Water tanks of $120 \mathrm{~L}$ were used in open system of substrate pots culture. The nutrient solution used in the experiment was adapted from Cooper (1979) depending on the analysis of the Local water by El-Behairy (1994). Plants were irrigated by using drippers of $4 \mathrm{~L} / \mathrm{hr}$ capacity. The fertigation was programmed to work 10 times / day and the duration of irrigation time depended upon the season. The EC of the different nutrient solutions were adjusted by using EC meter to the required level $\left(2.5 \mathrm{mmhos}^{-1}\right)$. The chemical compositions of vermi-Liquid, extract of commercial compost and chemical nutrient solution were illustrated in Table 1and the physical and chemical properties of vermicompost and commercial compost were indicated in Table 2.

Substrate physical properties i.e. bulk density (B.D), total pore space (T.P.S), water hold capacity \% (W.H.C) and air porosity \% (A.P) were estimated according to Wilson (1983) and Raul (1996). The $\mathrm{pH}$ of the potting mixtures were determined using a double distilled water suspension of each potting mixture in the ratio of 1:10 (w: v) (Inbaret al., 1993) that had been agitated mechanically for $2 \mathrm{~h}$ and filtered through Whatman no.1 filter paper. The same solution was measured for electrical conductivity with a conductance meter that had been standardized with 0.01 and $0.1 \mathrm{M} \mathrm{KCl}$.

Samples of three plants of each experimental plot were taken to determine growth parameters at 90 days from transplanting as follows: Plant height, leaves number/ plant and total leaves area/plant was recorded using a digital leaf area meter (LI-300 portable area meter produced by LI-COR, Lincoln, Nebraska, USA). Total plant fresh weight and dry weight was determined after oven-drying the samples at $70{ }^{\circ} \mathrm{C}$ for 48 hours. Yield measurements: early and total yield, physical properties for fruit i.e., average fruit length, diameter and weight.

Mineral analysis (N, P and K), plant samples of each plot were dried at $70^{\circ} \mathrm{C}$ in an air forced oven for 48 h. and dried leaves were digested in $\mathrm{H}_{2} \mathrm{SO}_{4}$ according to the method described by Allen (1974) and N, P and $\mathrm{K}$ contents were estimated in the acid digested solution. Total nitrogen was determined by micro Kjeldahl method according to the procedure described by FAO (1980). Phosphorus content was determined using spectrophotometer according to Watanabe and Olsen (1965). Potassium content was determined photo-metrically using Flame photometer as described by Chapman and Pratt (1961). The obtained data were statistically analyzed using the analysis of variance method according to Snedecor and Cocharn (1980). 
Table 1. Chemical composition of the different sources of nutrient solutions.

\begin{tabular}{lccccc|cccccccc}
\hline \multirow{2}{*}{$\begin{array}{c}\text { Nutrient } \\
\text { types }\end{array}$} & \multicolumn{4}{c|}{ Macro nutrients ppm } & \multicolumn{7}{c}{ Micro nutrients ppm } \\
\cline { 2 - 13 } & N & P & K & Ca & Mg & Fe & Mn & Zn & Cu & B & Pb & Cd \\
\hline Compost tea & $\mathbf{1 6 2}$ & $\mathbf{1 8 7}$ & $\mathbf{2 7 5}$ & $\mathbf{9 9}$ & $\mathbf{3 8}$ & $\mathbf{0 . 6 8}$ & $\mathbf{0 . 0 2}$ & $\mathbf{0 . 0 2}$ & $\mathbf{0 . 0 2}$ & $\mathbf{0 . 2 7}$ & $\mathbf{0 . 0 1 2}$ & n.d \\
Vermi-liquid & $\mathbf{1 2 8}$ & $\mathbf{1 8 1}$ & $\mathbf{3 2 2}$ & $\mathbf{1 1 1}$ & $\mathbf{4 8 . 6}$ & $\mathbf{0 . 2 5}$ & $\mathbf{0 . 0 4}$ & $\mathbf{0 . 0 1}$ & $\mathbf{0 . 0 4}$ & $\mathbf{0 . 2 1}$ & $\mathbf{0 . 0 4 7}$ & n.d \\
Chemical & $\mathbf{2 5 0}$ & $\mathbf{4 5}$ & $\mathbf{3 5 0}$ & $\mathbf{1 8 0}$ & $\mathbf{5 0}$ & $\mathbf{3 . 0}$ & $\mathbf{1}$ & $\mathbf{0 . 0 6}$ & $\mathbf{0 . 1 0}$ & $\mathbf{0 . 2 5}$ & $\mathbf{0 . 1 5 7}$ & $\mathbf{0 . 0 1 4}$ \\
\hline
\end{tabular}

Table 2. Physical and chemical properties of vermicompost and commercial compost

\begin{tabular}{|c|c|c|c|c|c|}
\hline \multicolumn{3}{|c|}{ Vermicompost } & \multicolumn{3}{|c|}{ Commercial compost } \\
\hline Analysis & UNITS & & Analysis & UNITS & \\
\hline B.D & $\mathrm{Kg} / \mathrm{m}^{3}$ & 715 & B.D & $\mathrm{Kg} / \mathrm{m}^{3}$ & 750 \\
\hline O. $\mathbf{M}$ & $\%$ & 33.22 & O. M & $\%$ & 45 \\
\hline $\mathrm{C} / \mathrm{N}$ ratio & & 1:12.27 & $\mathrm{C} / \mathrm{N}$ ratio & & 1:16.5 \\
\hline pH & & 8.17 & pH & & 7.5 \\
\hline EC & $\mathrm{dS} / \mathrm{m}$ & 6.67 & EC & $\mathrm{dS} / \mathrm{m}$ & 5.5 \\
\hline $\mathbf{N}$ & $\%$ & 1.57 & $\mathbf{N}$ & $\%$ & 1.8 \\
\hline N-NH4 & ppm & 65 & N-NH4 & ppm & - \\
\hline N-NO3 & ppm & 81 & $\mathrm{~N}-\mathrm{NO3}$ & ppm & - \\
\hline $\mathbf{P}$ & $\%$ & 1.27 & $\mathbf{P}$ & $\%$ & 0.8 \\
\hline $\mathbf{K}$ & $\%$ & 0.59 & $\mathbf{K}$ & $\%$ & 1.2 \\
\hline $\mathbf{F e}$ & ppm & 802 & $\mathbf{F e}$ & ppm & 2000 \\
\hline Mn & ppm & 143 & Mn & ppm & 150 \\
\hline $\mathbf{Z n}$ & ppm & 37.0 & $\mathbf{Z n}$ & ppm & 80 \\
\hline $\mathrm{Cu}$ & ppm & 14.0 & $\mathbf{C u}$ & ppm & 240 \\
\hline $\mathbf{P b}$ & ppm & 9.0 & $\mathbf{P b}$ & ppm & 10.03 \\
\hline Cd & ppm & n.d. & Cd & ppm & 0.96 \\
\hline
\end{tabular}

Bulk density (B.D) Organic matter (O.M)

\section{Results and Discussion}

The effect of commercial compost and vermicompost rate and different nutrient solution sources on:

The physical and chemical properties of different substrate mixtures:

The physical and chemical properties of different substrates mixtures of experiments are illustrated in Table 3. The obtained data indicate that increasing the rate of commercial compost (Nile compost) and vermicompost from 0 to $30 \%$ led to decrease in the bulk density (B.D) and air porosity (A.P) of sand mixtures, while total porosity of substrate (T.P.S) and water holding capacity (W.H.C) were increased.

The results of physical properties of sand mixtures presented clear similarity as a result of different rates of commercial compost and vermicompost application. The highest B.D of sand is desirable properties might be due to the vertical growth of cucumber that need to more stability and support with optimum moisture content respectively.

The bulk density of commercial compost and vermicompost is usually higher and the particle size lower than in some of the most commonly used peatbased substrates, mixing of those two substrates produces a significant increase in the bulk density and water holding capacity, while decreasing particle size and total porosity(Atiyeh et al, 2001); Bachman and Metzger, 2007). Hidalgo et al, (2006) reported a significant increase in T.P.S and WHC after addition of vermicompost to a greenhouse potting medium comprising with a mixture of sand, pine bark and peat. Limited studies on vermicompost indicated that it increases macro pore space, resulting in improved air-water relationship in the soil, which favorably affects plant growth; the application of organic matter including vermicompost favorably affects soil $\mathrm{pH}$, microbial population and soil enzyme activities (Karunaet al., 2011).

As a result of increasing commercial compost (Nile compost) and vermicompost rate in sand from 0 to 30 $\%$, E.C and O.M were increased regarding to the increase of organic compounds and high nutrient contents. The highest values of E.C and O.M were given by applying $30 \%$ of the commercial compost and vermicompost rate in sand mixture as illustrated in Table 3. These results agreed with Atiyehet al. (2001). While the increase in vermicompost rate led to a slight increase in $\mathrm{pH}$. Most of these results regarding physical and chemical propertiesare consistent with the results of Gutie'rrez-Miceliet al., (2007) and Manivannanet al. (2007). Regarding the chemical properties (EC and $\mathrm{pH}$ ), the obtained data indicated that increasing the rate of commercial compost and vermicompost led to increase in EC and $\mathrm{pH}$ of the different mixtures as a result of high contents of nutrients of commercial compost and vermicompost (Venugopalet al., 2010, Angelova et al. V.R., 2013 and Abul-Soudet al., 2014b). The 
current study focus on the organic soil matter content as a strong indicator while much of the research on vermicompost has focused on studying plant available nutrients and changes in soil structure via soil porosity, aeration, and moisture holding capacity (Hashemimajdet al., 2004 and Tejadaet al., 2010).

Table 3. The physical and chemical properties of different substrates.

\begin{tabular}{|c|c|c|c|c|c|c|c|}
\hline \multicolumn{6}{|c|}{ Physical } & \multicolumn{2}{|c|}{ Chemical } \\
\hline Substrate & $\begin{array}{c}\text { B.D } \\
\mathrm{Kg} / \mathrm{m}^{3}\end{array}$ & T.P.S \% & W.H.C \% & $\begin{array}{l}\text { A.P } \\
\%\end{array}$ & $\begin{array}{l}\text { E.C } \\
\text { ds } \backslash \mathrm{m}\end{array}$ & $\mathrm{pH}$ & O.M\% \\
\hline Sand $100 \%$ & 1.67 & 26 & 17.8 & 8.2 & 0.4 & 7.6 & 0.2 \\
\hline S 90\%: C $10 \%$ & 1.5 & 32.4 & 23.2 & 9.2 & 1.2 & 7.7 & 1.69 \\
\hline S $80 \%$ : C $20 \%$ & 1.44 & 35.6 & 27.5 & 8.1 & 1.8 & 7.7 & 3.46 \\
\hline S 70\%: C $30 \%$ & 1.36 & 37.1 & 31.3 & 5.8 & 2.1 & 7.8 & 5.33 \\
\hline S 90\%:V.C10\% & 1.6 & 32.7 & 26.4 & 6.3 & 0.61 & 7.7 & 1.18 \\
\hline S 80\%:V.C20\% & 1.56 & 37.2 & 33.1 & 4.1 & 0.9 & 7.8 & 2.43 \\
\hline S 70\%:V.C30\% & 1.52 & 43.1 & 39.5 & 3.6 & 1.07 & 7.8 & 3.75 \\
\hline
\end{tabular}

Bulk density (B.D). Total poor space (T.P.S).Water holding capacity (W.H.C).Air porosity (A.P).Organic matter (O.M)

Vegetative growth parameters of cucumber:

Data in Table 4 show the effect of different nutrient solution sources, substrates amendments and their interaction on growth characteristics of cucumber plants expressed as plant height, number and area of leaves/plant and fresh and dry weight/plant in studied seasons. Data show that using inorganic nutrient solution gave significant highest values of vegetative growth characteristics compared to the different fertigation sources, organic fertilizers (compost tea and vermi-liquid). The statistical analysis of the obtained data revealed no significant differences between compost tea and vermi-liquied.

These findings were true for the two experimental seasons as well as for all plant growth parameters that mention above. Also the presented data detected that, with using vermi-liquid and compost tea as a nutrient solution caused gradually and consistant depression in the values of plant growth parameters. Many workers among them Abou-El-Hassan et al. (2008) andAboSedera et al (2015) reported that, vegetative growth of vegetable plants significantly improved with inorganic nutrient solution compared to the other organic different nutrient solution. In this respect Al-Redhaimanet al. (2005) stated that there were significant influences for different nutrient sources "inorganic source and chicken manure and rabbit manure as a natural organic source" on growth of lettuce plants under hydroponic condition. They noticed that the highest fresh and dry weight of lettuce head was observed with inorganic fertilizer solution, while the lowest values were recorded with chicken manure extract. On the contrary, other authors such as Mancy (2013) detected that the use of different sources of organic nutrients supply (chicken or El-obour compost tea) increased vegetative growth parameters of cucumber plant (plant height, number of leaves, total fresh and dry weights). But the obtained values in the case of compost tea (chicken and El-obour) were lower than Hoagland nutrient solution.

Regarding to the substrate culture, generally data indicated that using vermicompost as a substrate culture mixed with sand culture $(20: 80 \mathrm{v} / \mathrm{v})$ gave mostly the highest value of vegetative growth parameter i.e. (plant height, leaf number, leaf area, fresh and dry weight of plant), followed in a descending order by plants which grown with vermicompost + sand $(30 \%+70 \%)$, then that plants with compost + sand $(30 \%+70 \%$ respectively. The statistical analysis detected no significant variation within the above mentioned substrates. As general, the obtained data reveals that, with increasing the rate of both vermicompost and compost, the better plant growth parameters were recorded. These findings are in good accordance during the two experimental seasons for all plant growth.

Concerning to the interaction between different nutrient solutions and substrates on plant growth characters of cucumber during the two experimental seasons is shown in Table 4. It is seen that the statistical analysis of the interaction effect between these treatments on all growth parameters were significant. However, using growing media contained $80 \%$ sand $+20 \%$ vermicompost under nutrient solution had the tallest cucumber plants which carried the highest number and area of leaves as well as the heaviest fresh and dry weight of plant. On the contrary, growing cucumber in substrate contains only sand (control) resulted in the weak plants, i.e. the shortest plants which contain the lowest number and area of leaves as well as fresh and dry weight of plant. These were true with different nutrient solution in both experimental seasons. 
Table 4. Effect of different nutrient solution sources, substrate amendments and their interaction on growth characteristics of cucumber plants in the first season (2012).

\begin{tabular}{|c|c|c|c|c|c|c|c|}
\hline & & & first sea & (2012) & & & \\
\hline & Treatments & Plant height & No .of leaves/ & Fresh weight/ plant & Dry weight/ & & Leaf area \\
\hline & N.S & 2.85 & 58.60 & 409.55 & 60.61 & 0.80 & 3627.41 \\
\hline Fertigation & V.L & 8.59 & 48.98 & 344.14 & $\mathbf{5 3 . 5 7}$ & 0.70 & 2857.68 \\
\hline & C.T & 8.36 & 48.79 & 321.47 & 53.67 & 0.62 & 2861.76 \\
\hline L.S.D at 0.05 & & .890 & 3.63 & 8.89 & 1.81 & 0.06 & 37.54 \\
\hline & Sand $100 \%$ ( control ) & 148.36 & 5.14 & 221.37 & 2.75 & 0.60 & 2934.67 \\
\hline & S.90\%+ C $10 \%$ & 199.18 & 9.92 & 304.14 & 8.23 & 0.66 & 3063.74 \\
\hline & S $80 \%+$ C $20 \%$ & 236.18 & 4.14 & 358.66 & 5.37 & 0.76 & 3108.52 \\
\hline Substrates & S 70\% + C $30 \%$ & 250.10 & 7.88 & 408.11 & 2.70 & 0.76 & 3163.70 \\
\hline & S.90\%+V.C $10 \%$ & 236.18 & 8.81 & 379.14 & 7.24 & 0.64 & 3096.93 \\
\hline & S $80 \%+$ V.C $20 \%$ & 260.33 & 4.81 & 419.40 & 3.89 & 0.77 & 3250.48 \\
\hline & S 70\% + V.C30\% & 255.96 & 6.48 & 417.88 & 1.48 & 0.75 & 3191.30 \\
\hline L.S.D at 0.05 & & 0.52 & .550 & 13.58 & .760 & 0.09 & 57.34 \\
\hline & Sand $100 \%$ ( control ) & 190.55 & 46.22 & 279.89 & 47.22 & 0.70 & 3225.78 \\
\hline & $\mathrm{S} .90 \%+\mathrm{C} 10 \%$ & 218.99 & 56.77 & 355.22 & 52.71 & 0.76 & 3545.67 \\
\hline & S $80 \%+$ C $20 \%$ & 235.88 & 62.88 & 398.78 & 59.51 & 0.93 & 3608.67 \\
\hline Nutrient & $\mathrm{S} 70 \%+\mathrm{C} 30 \%$ & 268.10 & 62.55 & 446.44 & 63.87 & 0.83 & 3734.56 \\
\hline & S.90\%+V.C $10 \%$ & 234.66 & 53.44 & 430.11 & 62.28 & 0.63 & 3616.45 \\
\hline & S $80 \%+$ V.C $20 \%$ & 278.55 & 65.55 & 484.56 & 72.40 & 0.93 & 3860.11 \\
\hline & S 70\% + V.C30\% & 273.22 & 62.77 & 471.89 & 66.28 & 0.83 & 3800.67 \\
\hline & Sand $100 \%$ ( control ) & 130.55 & 41.66 & 209.67 & 40.64 & 0.60 & 2790.33 \\
\hline & $\mathrm{S} .90 \%+\mathrm{C} 10 \%$ & 185.10 & 48.44 & 319.11 & 46.27 & 0.66 & 2813.67 \\
\hline & S $80 \%+$ C $20 \%$ & 234.66 & 52.00 & 340.44 & 52.20 & 0.73 & 2856.78 \\
\hline vermı- & S $70 \%+$ C $30 \%$ & 241.66 & 53.77 & 407.00 & 64.20 & 0.73 & 2889.00 \\
\hline & S.90\%+V.C $10 \%$ & 235.66 & 45.00 & 358.89 & 54.56 & 0.70 & 2846.89 \\
\hline & S $80 \%+$ V.C $20 \%$ & 250.99 & 46.88 & 389.11 & 57.75 & 0.73 & 2961.00 \\
\hline & S 70\% + V.C30\% & 251.55 & 53.77 & 384.78 & 59.41 & 0.73 & 2846.11 \\
\hline & Sand $100 \%$ ( control ) & 124.00 & 47.55 & 174.56 & 40.40 & 0.50 & 2787.89 \\
\hline & $5.90 \%+C 10 \%$ & 193.44 & 44.55 & 238.11 & 45.71 & 0.56 & 2831.89 \\
\hline & S $80 \%+$ C $20 \%$ & 237.99 & 47.55 & 336.78 & 54.42 & 0.63 & 2860.11 \\
\hline Compost & S $70 \%+$ C $30 \%$ & 240.55 & 57.33 & 370.89 & 60.04 & 0.73 & 2867.56 \\
\hline & S.90\%+V.C $10 \%$ & 237.99 & 48.00 & 348.44 & 54.87 & 0.60 & 2827.44 \\
\hline & S $80 \%+$ V.C $20 \%$ & 251.44 & 52.00 & 384.56 & 61.53 & 0.66 & 2930.33 \\
\hline & S 70\% + V.C30\% & 243.11 & 52.88 & 397.00 & 58.75 & 0.70 & 2927.11 \\
\hline L.S.D at 0.05 & & .520 & 9.56 & 24.12 & .91 & 0.16 & 96.95 \\
\hline
\end{tabular}

* N.S Nutrient Solution, V.L Vermin Liquid, C.T Compost Tea

** Sand $90 \%$ : commercial compost $10 \%$, sand $80 \%$ : commercial compost $20 \%$, sand $70 \%$ : commercial compost $30 \%$, Sand $90 \%$ : vermicompost $10 \%$, Sand $80 \%$ : vermicompost $20 \%$, Sand $70 \%$ : vermicompost $30 \%$.

$* * *$ L.S.D at 0.05

These results are compatible with Singh and Chauhan (2009).Roy et al. (2010), andFernándezLuqueño et al.(2010) and AboSedera et al (2015) on common bean (Phaseolusvulgaris.L) plants. As affirmed by Rasool et al., 2009 on cucumber (Cucumis sativus L.). Senthilkumaret al.(2004) found that vermicompost with or without NPK fertilizers significantly enhanced rose growth, yield and quality over the untreated control, especially when used in combination. On the contrary, Venugopalet al., (2010) and Abul-Soudet al., (2014b)detected thatvermicompost could be used as a natural fertilizer having a number of advantages over chemical fertilizers, possibly due to better physical properties, higher microbial and enzymatic activity and higher content of available nutrients producer acceptance of vermicompost is greater than that of compost. 
Table 4. Effect of different nutrient solution sources, substrate amendments and their interaction on growth characteristics of cucumber plants in the second season (2013).

\begin{tabular}{|c|c|c|c|c|c|c|c|}
\hline \multirow{2}{*}{\multicolumn{2}{|c|}{ Treatments }} & \multicolumn{4}{|c|}{ second season (2013) } & \multirow{2}{*}{$\begin{array}{c}\text { Stem } \\
\text { diameter } \\
\text { (C.m) }\end{array}$} & \multirow{2}{*}{$\begin{array}{l}\text { Leaf area } \\
\text { plant } /\left(\mathrm{cm}^{2}\right)\end{array}$} \\
\hline & & Plant height & No. of leaves/ & Fresh weight/ plant & Dry weight/ & & \\
\hline \multirow{3}{*}{$\begin{array}{l}\text { Fertigation } \\
\text { sources }\end{array}$} & N.S & 245.76 & 66.77 & 21.2 & 3.78 & 0.80 & 3700.56 \\
\hline & V.L & 220.65 & 48.08 & 49.5 & 2.50 & 0.72 & 864.86 \\
\hline & C.T & 202.49 & 46.77 & 46.6 & 4.04 & 0.64 & 871.38 \\
\hline \multirow[t]{4}{*}{ L.S.D at 0.05} & & 5.20 & 3.47 & 680 & .790 & 0.06 & 5.67 \\
\hline & Sand $100 \%$ ( control ) & 190.40 & 4.44 & 265.25 & 7.59 & 0.66 & 899.2 \\
\hline & $\mathrm{S} .90 \%+\mathrm{C} 10 \%$ & 197.18 & 0.25 & 306.70 & 0.01 & 0.63 & 043.78 \\
\hline & S $80 \%+$ C $20 \%$ & 210.03 & 0.07 & 381.77 & 9.38 & 0.67 & 165.00 \\
\hline \multirow[t]{4}{*}{ Substrates } & S $70 \%+$ C $30 \%$ & 226.92 & 8.14 & 446.92 & 7.92 & 0.71 & 235.63 \\
\hline & S.90\%+V.C $10 \%$ & 228.07 & 2.48 & 342.77 & 4.41 & 0.73 & 133.52 \\
\hline & S $80 \%+$ V.C $20 \%$ & 251.70 & 1.77 & 438.25 & 3.34 & 0.75 & 275.37 \\
\hline & S 70\% + V.C30\% & 256.44 & 9.88 & 425.81 & 4.78 & 0.90 & 266.67 \\
\hline \multirow[t]{3}{*}{ L.S.D at 0.05} & & 7.95 & 5.31 & 13.26 & .730 & 0.09 & 5.04 \\
\hline & Sand $100 \%$ ( control ) & 214.44 & 56.44 & 46.22 & 54.62 & 0.73 & 3225.48 \\
\hline & S.90\%+ C $10 \%$ & 227.22 & 70.00 & 61.33 & 58.01 & 0.73 & 3478.67 \\
\hline \multirow{5}{*}{$\begin{array}{l}\text { Nutrient } \\
\text { solution }\end{array}$} & S $80 \%+$ C $20 \%$ & 242.11 & 65.55 & 10.11 & 61.05 & 0.76 & 3767.00 \\
\hline & S $70 \%+$ C $30 \%$ & 265.00 & 66.55 & 40.67 & 64.07 & 0.86 & 3884.00 \\
\hline & S.90\%+V.C $10 \%$ & 231.66 & 64.88 & 94.22 & 64.83 & 0.66 & 3643.67 \\
\hline & S $80 \%+$ V.C $20 \%$ & 263.44 & 74.22 & 15.00 & 71.11 & 0.88 & 3917.33 \\
\hline & S 70\% + V.C30\% & 276.44 & 69.77 & 81.33 & 72.81 & 1.13 & 3987.78 \\
\hline \multirow{7}{*}{$\begin{array}{l}\text { Vermi- } \\
\text { liquid }\end{array}$} & Sand $100 \%$ ( control ) & 193.00 & 43.44 & 22.89 & 4.23 & 0.63 & 2692.44 \\
\hline & $\mathrm{S} .90 \%+\mathrm{C} 10 \%$ & 192.33 & 45.33 & 72.78 & 5.04 & 0.63 & 2817.22 \\
\hline & S $80 \%+$ C $20 \%$ & 212.11 & 42.11 & 87.67 & 7.07 & 0.70 & 2849.22 \\
\hline & S $70 \%+$ C $30 \%$ & 220.22 & 53.11 & 46.11 & 5.93 & 0.73 & 2912.78 \\
\hline & S.90\%+V.C $10 \%$ & 221.00 & 44.11 & 32.00 & 0.42 & 0.83 & 2874.44 \\
\hline & S $80 \%+$ V.C $20 \%$ & 256.33 & 55.00 & 95.44 & 0.08 & 0.83 & 2960.56 \\
\hline & S 70\% + V.C30\% & 249.55 & 53.22 & 90.11 & 4.70 & 0.73 & 2947.33 \\
\hline \multirow{7}{*}{$\begin{array}{l}\text { Compost } \\
\text { tea }\end{array}$} & Sand $100 \%$ ( control ) & 163.77 & 33.44 & 26.67 & 3.93 & 0.53 & 2779.78 \\
\hline & $\mathrm{S} .90 \%+\mathrm{C} 10 \%$ & 172.0 & 35.44 & 86.00 & 6.97 & 0.53 & 2835.44 \\
\hline & S $80 \%+$ C $20 \%$ & 175.88 & 42.55 & 47.56 & 0.01 & 0.56 & 2878.78 \\
\hline & S $70 \%+$ C $30 \%$ & 195.55 & 54.77 & 54.00 & 3.75 & 0.54 & 2910.11 \\
\hline & S.90\%+V.C $10 \%$ & 231.66 & 48.44 & 02.11 & 7.98 & 0.70 & 2882.44 \\
\hline & S $80 \%+$ V.C $20 \%$ & 235.33 & 56.11 & 04.33 & 8.82 & 0.70 & 2948.22 \\
\hline & S 70\% + V.C30\% & 243.33 & 56.66 & 06.00 & 6.85 & 0.83 & 4864.89 \\
\hline \multicolumn{2}{|l|}{ L.S.D at 0.05} & 13.27 & 9.14 & 3.34 & .43 & 0.17 & 150.25 \\
\hline
\end{tabular}

* N.S Nutrient Solution, V.L Vermin Liquid, C.T Compost Tea

** Sand $90 \%$ : commercial compost $10 \%$, sand $80 \%$ : commercial compost $20 \%$, sand $70 \%$ : commercial compost $30 \%$, Sand $90 \%$ : vermicompost $10 \%$, Sand $80 \%$ : vermicompost $20 \%$, Sand 70\%: vermicompost $30 \%$.

$* * *$ L.S.D at 0.05

Yield:

The Effect of different nutrient solutions and sand mixtures on the early and total yield of cucumber (kg/plant) is presented in Table 5. Regarding the effect of nutrient solution types, data show that using the chemical nutrient solution resulted in the highest total and early yield, but the lowest values were recorded with that plants which grown under using compost tea as nutrient solution. Whereas the superiority amounted by $51.1 \%, 35 \%$ and $34.9 \%$ respectively for early, total yield as $\mathrm{kg} /$ plant and total yield as $\mathrm{kg} / \mathrm{m}^{2}$ in the first season. But, in the second season it amounted by $62 \%, 59.2 \%$ and $59.3 \%$ for the same respective. It means that using compost tea reduced early, total yield/ plant and total yield/ $\mathrm{m}^{2}$ comparing with using the inorganic nutrient solution (control).There were a significant differences between different nutrient solution in both seasons. Obtained results are in agreement with those reported by George et al. (2007), Gutiérrez-Miceli et al.
(2008), Abou-El-Hassan et al. (2008). And AboSedera et al (2015).

Concerning the effect of different substrates amendment on the early and total cucumber yield, data presented in Table 6 indicate that, growing cucumber plants in substrate contained $80 \%$ sand + $20 \%$ vermicompost resulted in the heaviest early and total cucumber yield, followed in a descending order by that plants which grown in $70 \%$ sand+ $30 \%$ vermicompost, then that substrate which contains $70 \%$ sand $+30 \%$ commercial compost, where in most cases, there were significant differences detected within the substrates at $5 \%$ level. On the contrary, using only sand (control) as growing substance gave the lowest total and early yield. All these finding are completely similar in both experimental seasons.

These results are in accordance by AboSedera et al (2015), they reported that using vermicompost mixed with sand culture $(20: 80 \mathrm{v} / \mathrm{v})$ gave the highest value of early and total yield/ plant and total yield/ $\mathrm{m}^{2}$ of 
snap bean.Moreover, Ramachandraet al., (1998) and Arancon et al., (2004) on strawberry, had good results which support that written herein.

Regarding the effect of interaction between different nutrient solution and sand mixtures on the all measured yield parameters of cucumber, data in Table.5 show that greatest early, total yield/ plant and total yield $/ \mathrm{m}^{2}$ was obtained from vermicompost $20 \%+$ sand $80 \%$ and vermicompost $30 \%$ + sand $70 \%$ as compared with inorganic nutrient solution during the first and second seasons. The lowest values of all measured yield items were obtained from without any addition of commercial compost and vermicompost (control) with compost tea as a nutrient solution as follow sand $100 \%$ (control) with vermi-liquid.

With regard to the effect of the interaction, the same data reveal that using chemical nutrient solution combined with substrate of sand with the addition of vermicompost at the highest used rate $(20 \%$ or $30 \%)$ exhibited the highest values for all determined yield parameters during both seasons of study.

In addition, there is evidence that vermicompost added to plant media increases growth, flowering and fruiting of vegetables (Atiyeh et al., 2000). such as (Arancon et al., 2008, Amir and Fouzia, 2011, Abul-Soud et al., (2014) and Senthilkumar et al., 2004) on peas.

Table 5: Effect of different nutrient solution sources, substrate amendments and their interaction on cucumber yield $(\mathrm{kg})$ during the first season (2012).

\begin{tabular}{|c|c|c|c|c|c|}
\hline & \multirow[b]{2}{*}{ Treatments } & \multicolumn{3}{|c|}{ first season (2012) } & \multirow[b]{2}{*}{ Total yield $/ \mathrm{m}^{2}(\mathrm{Kg})$} \\
\hline & & No. of fruits /plant & $\begin{array}{c}\text { Early yield / plant } \\
(\mathrm{kg})\end{array}$ & $\begin{array}{c}\text { Early yield } / \mathrm{m}^{2} \\
(\mathrm{Kg})\end{array}$ & \\
\hline \multirow{3}{*}{$\begin{array}{l}\text { Fertigation } \\
\text { sources }\end{array}$} & N.S & 26.57 & 0.591 & 2.36 & 9.464 \\
\hline & V.L & 21.49 & 0.441 & 1.79 & 7.156 \\
\hline & C.T & 21.01 & 0.391 & 1.75 & 7.014 \\
\hline \multirow[t]{4}{*}{ L.S.D at 0.05} & & 1.51 & 0.03 & 0.13 & 0.55 \\
\hline & Sand $100 \%$ ( control ) & 18.22 & 0.300 & 1.20 & 4.812 \\
\hline & $\mathrm{S} .90 \%+\mathrm{C} 10 \%$ & 19.70 & 0.363 & 1.45 & 5.813 \\
\hline & S $80 \%+$ C $20 \%$ & 21.77 & 0.466 & 1.86 & 7.459 \\
\hline \multirow[t]{4}{*}{ Substrates } & S $70 \%+$ C $30 \%$ & 24.81 & 0.605 & 2.42 & 9.680 \\
\hline & S.90\%+V.C $10 \%$ & 20.96 & 0.382 & $\mathbf{1 . 5 3}$ & 6.112 \\
\hline & S $80 \%+$ V.C $20 \%$ & 27.40 & 0.663 & 2.65 & 10.615 \\
\hline & S 70\% + V.C30\% & 28.29 & 0.651 & 2.60 & 10.420 \\
\hline \multirow[t]{3}{*}{ L.S.D at 0.05} & & 2.31 & 0.05 & 0.21 & 0.85 \\
\hline & Sand $100 \%$ ( control ) & 23.11 & 0.405 & 1.62 & 6.494 \\
\hline & $5.90 \%+\mathrm{C} 10 \%$ & 23.44 & 0.453 & 1.81 & 7.259 \\
\hline \multirow{7}{*}{$\begin{array}{l}\text { Nutrient } \\
\text { solution }\end{array}$} & S $80 \%+$ C $20 \%$ & 25.00 & 0.532 & 2.13 & 8.519 \\
\hline & S $70 \%+$ C $30 \%$ & 28.00 & 0.692 & 2.77 & 11.074 \\
\hline & S.90\%+V.C $10 \%$ & 23.00 & 0.440 & 1.76 & 7.051 \\
\hline & S $80 \%+$ V.C $20 \%$ & 32.66 & 0.838 & 3.35 & 13.418 \\
\hline & S 70\% + V.C30\% & 30.77 & 0.776 & 3.10 & 12.430 \\
\hline & Sand $100 \%$ ( control ) & 16.44 & 0.256 & 1.02 & 4.103 \\
\hline & $\mathrm{S} .90 \%+\mathrm{C} 10 \%$ & 18.22 & 0.331 & 1.32 & 5.307 \\
\hline \multirow{7}{*}{$\begin{array}{l}\text { Vermi- } \\
\text { liquid }\end{array}$} & S $80 \%+$ C $20 \%$ & 19.77 & 0.419 & 1.67 & 6.707 \\
\hline & S 70\% + C 30\% & 23.11 & 0.543 & 2.17 & 8.691 \\
\hline & S.90\%+V.C $10 \%$ & 20.33 & 0.350 & 1.40 & 5.612 \\
\hline & S $80 \%+$ V.C $20 \%$ & 24.66 & 0.575 & 2.30 & 9.200 \\
\hline & S 70\% + V.C30\% & 27.88 & 0.610 & 2.44 & 9.770 \\
\hline & Sand $100 \%$ ( control ) & 15.11 & 0.239 & 0.96 & 3.838 \\
\hline & $\mathrm{S} .90 \%+\mathrm{C} 10 \%$ & 17.44 & 0.304 & 1.22 & 4.874 \\
\hline \multirow{5}{*}{$\begin{array}{c}\text { Compost } \\
\text { tea }\end{array}$} & S $80 \%+$ C $20 \%$ & 20.55 & 0.446 & 1.78 & 7.150 \\
\hline & S $70 \%+$ C $30 \%$ & 23.33 & 0.579 & 2.32 & 9.276 \\
\hline & S.90\%+V.C $10 \%$ & 19.55 & 0.354 & 1.42 & 5.672 \\
\hline & S $80 \%+$ V.C $20 \%$ & 24.88 & 0.576 & 2.30 & 9.227 \\
\hline & S 70\% + V.C30\% & 26.22 & 0.566 & 2.26 & 9.060 \\
\hline \multicolumn{2}{|l|}{ L.S.D at 0.05} & 3.91 & 0.09 & 0.36 & 1.44 \\
\hline
\end{tabular}

N.S Nutrient Solution, V.L Vermin Liquid, C.T Compost Tea

Sand $90 \%$ : commercial compost $10 \%$, sand $80 \%$ : commercial compost $20 \%$, sand $70 \%$ : commercial compost $30 \%$, Sand $90 \%$ : vermicompost $10 \%$, Sand $80 \%$ : vermicompost $20 \%$, Sand $70 \%$ : vermicompost $30 \%$.

L.S.D at 0.05 
Table 5. Effect of different nutrient solution sources, substrate amendments and their interaction on cucumber yield (kg) during the second season (2013).

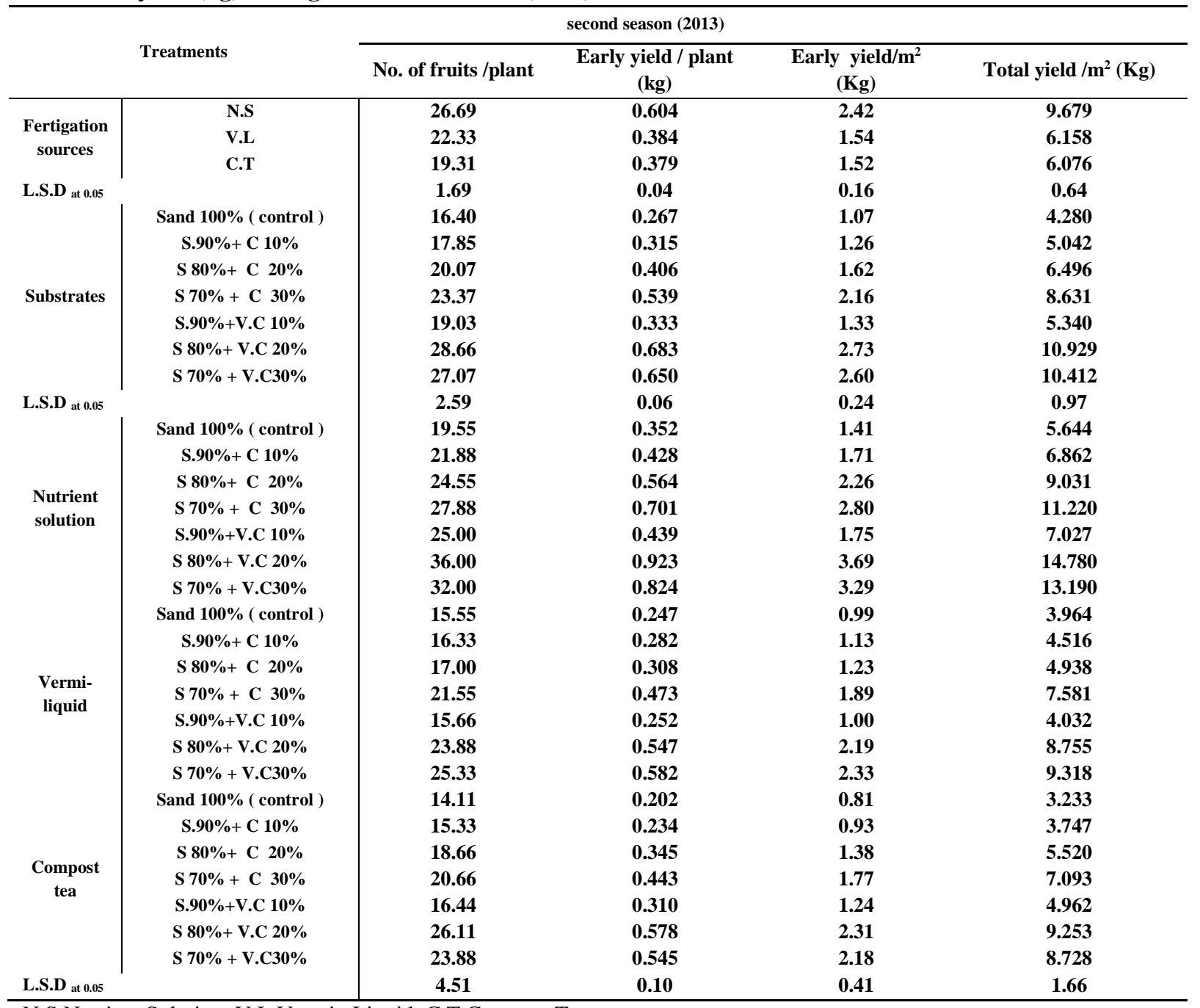

N.S Nutrient Solution, V.L Vermin Liquid, C.T Compost Tea

Sand $90 \%$ : commercial compost $10 \%$, sand $80 \%$ : commercial compost $20 \%$, sand $70 \%$ : commercial compost $30 \%$, Sand $90 \%$ : vermicompost $10 \%$, Sand $80 \%$ : vermicompost $20 \%$, Sand $70 \%$ : vermicompost $30 \%$.

L.S.D at 0.05

Macro nutrient content (\%):

The effect of different nutrient solution, substrate mixture and their interaction on macro nutrients content $(\mathrm{N}, \mathrm{P}$ and $\mathrm{K})$ in cucumber plants are illustrated in Table 6. The obtained data show that there were significant differences among tested nutrient solutions. In this respect, inorganic nutrient solution treatment recorded the highest values of $\mathrm{N}$, $\mathrm{P}$ and $\mathrm{K}$ content compared to another nutrient solutions used in this study, while the lowest value was recorded by using compost tea.

This result is in according with numerous workers, who reported that using chemical nutrient solution led to increase macro nutrients content of snap bean leaves among Aboul-soud. (2005), Abou-El-Hassan et al. (2008) and Abo Sedera et al (2015). They reported that N,P and $\mathrm{K}$ content in cucumber, cantaloupe and snap bean leaves increased by using inorganic nutrient solution comparing to compost tea.
Increasing the commercial compost and vermicompost rate from 10 to $30 \%$ with sand increased $\mathrm{N}, \mathrm{P}$ and $\mathrm{K}$ content in cucumber leaves, while using vermicompost $30 \%+70 \%$ sand as followed by vermicompost $20 \%+80 \%$ sand gave the highest value of $\mathrm{N}$ and $\mathrm{P}$ content in the first season, while in the second season the highest value was observed by vermicompost $20 \%+$ sand $80 \%$. On the contrary the lowest value was noticed by using sand $100 \%$ (control).

Regarding the effect of the interaction between different fertilizers (inorganic nutrient solution, organic compost tea and vermi-liquid) and substrate mixtures on $\mathrm{N}, \mathrm{P}$ and $\mathrm{K}$ content results in Table 6 illustrate that using organic nutrient solution (compost tea) with sand $100 \%$ gave the lowest values of $\mathrm{P}$ and $\mathrm{K}$ content in cucumber leaves in the first season, otherwise, the lowest value from $\mathrm{N}$ content was noticed when used the organic nutrient solution 
(vermin liquid) + sand $100 \%$, but the highest values of $\mathrm{N}$ and $\mathrm{P}$ were obtained by inorganic nutrient solution with sand $70 \%+30 \%$ vermicompost. However, when inorganic nutrient solution with sand $80 \%+20 \%$ vermicompost recorded the highest value of $\mathrm{K}$ content in cucumber leaves, while in the second season the highest values of $\mathrm{N}, \mathrm{P}$ and $\mathrm{K}$ recorded by chemical nutrient solution combined with $80 \%$ sand $+20 \%$ vermicompost, while the lowest values of $\mathrm{N}$, $\mathrm{P}$ and $\mathrm{K}$ content were recorded by sand $100 \%$ (control) combined with organic nutrient solution (compost tea) with significant difference.

These results are in agreement with Abou-soud (2005) and Abou-El-Hassan et al. (2008), who reported that $\mathrm{N}, \mathrm{P}$ and $\mathrm{K}$ content in cucumber and cantaloupe leaves were increased by using inorganic nutrient solution with increasing organic matter levels in the substrate culture comparing to different compost tea types. Atiyeh et al. (2000a) found that compost was higher in ammonium, while vermicompost tended to be higher in nitrates, which is the more plant-available form of nitrogen. Similarly, Hammermeister et al. (2004) indicated that Vermicomposted manure has higher $\mathrm{N}$ availability than conventionally composted manure on a weight basis. The latter study also showed that the supply rate of several nutrients, including $\mathrm{P}, \mathrm{K}, \mathrm{S}$ and $\mathrm{Mg}$, were increased by vermicomposting as compared with conventional composting.

Table 6: Effect of different nutrient solution sources, substrate amendments and their interaction on chlorophyll reading, $\mathbf{N}, \mathbf{P}$ and $\mathrm{K}(\%)$ of cucumber plant foliage in the two seasons (2012-2013).

\begin{tabular}{|c|c|c|c|c|c|c|c|}
\hline \multirow{2}{*}{\multicolumn{2}{|c|}{ Treatments }} & \multicolumn{3}{|c|}{ first season (2012) } & \multicolumn{3}{|c|}{ second season (2013) } \\
\hline & & $\mathbf{N}(\%)$ & $\mathbf{P}(\%)$ & $\mathbf{K}(\%)$ & $\mathbf{N}(\%)$ & $\mathbf{P}(\%)$ & $\mathbf{K}(\%)$ \\
\hline \multirow{3}{*}{$\begin{array}{c}\text { Fertigation } \\
\text { sources }\end{array}$} & N.S & 4.68 & 0.3 & 3.44 & 4.52 & 1.00 & 3.59 \\
\hline & V.L & 2.90 & 0.8 & 3.34 & 3.07 & 0.77 & 3.55 \\
\hline & C.T & 2.89 & 0.1 & 3.26 & 2.81 & 0.69 & 3.24 \\
\hline \multirow[t]{4}{*}{ L.S.D at 0.05} & & 0.11 & 0.07 & n.s & 0.18 & 0.05 & 0.14 \\
\hline & Sand $100 \%$ (control) & 2.80 & 0.63 & 2.58 & 2.73 & 0.70 & 2.98 \\
\hline & $\mathrm{S} .90 \%+\mathrm{C} 10 \%$ & 2.93 & 0.70 & 3.06 & 2.73 & 0.73 & 3.08 \\
\hline & S $80 \%+$ C $20 \%$ & 3.53 & 0.77 & 3.33 & 3.78 & 0.79 & 3.29 \\
\hline \multirow[t]{4}{*}{ Substrates } & $\mathrm{S} 70 \%+\mathrm{C} 30 \%$ & 3.83 & 0.86 & 3.73 & 4.04 & 0.90 & 3.85 \\
\hline & S.90\%+V.C $10 \%$ & 3.17 & 0.72 & 3.22 & 2.89 & 0.75 & 2.98 \\
\hline & S $80 \%+$ V.C $20 \%$ & 4.00 & 0.93 & 3.91 & 4.13 & 0.98 & 3.92 \\
\hline & S 70\% + V.C30\% & 4.16 & 1.03 & 3.60 & 3.98 & 0.96 & 4.11 \\
\hline \multirow[t]{3}{*}{ L.S.D at 0.05} & & 0.17 & 0.10 & 0.31 & 0.28 & 0.07 & 0.22 \\
\hline & Sand $100 \%$ (control) & 2.91 & 0.7 & 2.74 & 2.82 & 0.79 & 3.02 \\
\hline & S.90\%+ C $10 \%$ & 3.34 & 0.3 & 3.03 & 2.94 & 0.84 & 3.33 \\
\hline \multirow{5}{*}{$\begin{array}{l}\text { Nutrient } \\
\text { solution }\end{array}$} & S $80 \%+$ C $20 \%$ & 5.01 & 0.7 & 3.39 & 5.05 & 0.84 & 3.37 \\
\hline & S 70\% + C 30\% & 5.38 & 0.1 & 3.95 & 5.55 & 1.04 & 3.96 \\
\hline & S.90\%+V.C 10\% & 4.09 & 0.4 & 3.00 & 3.44 & 0.89 & 2.97 \\
\hline & S $80 \%+$ V.C $20 \%$ & 5.99 & 1.2 & 4.01 & 5.97 & 1.36 & 4.25 \\
\hline & S 70\% + V.C30\% & 6.05 & 1.5 & 3.97 & 5.92 & 1.23 & 4.20 \\
\hline \multirow{7}{*}{$\begin{array}{l}\text { Vermi- } \\
\text { liquid }\end{array}$} & Sand $100 \%$ (control) & 2.74 & 0.8 & 2.74 & 2.83 & 0.66 & 2.96 \\
\hline & S.90\%+C $10 \%$ & 2.76 & 0.0 & 3.09 & 2.58 & 0.67 & 3.04 \\
\hline & S $80 \%+$ C $20 \%$ & 2.87 & 0.4 & 3.32 & 3.37 & 0.78 & 3.47 \\
\hline & S $70 \%+$ C $30 \%$ & 2.98 & 0.5 & 3.82 & 3.77 & 0.88 & 3.77 \\
\hline & S.90\%+V.C 10\% & 2.75 & 0.7 & 3.27 & 2.70 & 0.67 & 3.31 \\
\hline & S $80 \%+$ V.C $20 \%$ & 3.12 & 0.4 & 3.83 & 3.19 & 0.80 & 3.95 \\
\hline & S 70\% + V.C30\% & 3.07 & 0.1 & 3.33 & 3.10 & 0.91 & 4.01 \\
\hline \multirow{7}{*}{$\begin{array}{c}\text { Compost } \\
\text { tea }\end{array}$} & Sand $100 \%$ (control) & 2.75 & 0.4 & 2.28 & 2.54 & 0.64 & 2.96 \\
\hline & S.90\%+ C $10 \%$ & 2.68 & 0.8 & 3.04 & 2.67 & 0.67 & 2.88 \\
\hline & $\mathrm{S} 80 \%+\mathrm{C} 20 \%$ & 2.71 & 0.0 & 3.28 & 2.93 & 0.77 & 3.04 \\
\hline & S $70 \%+$ C $30 \%$ & 3.13 & 0.3 & 3.43 & 3.11 & 0.78 & 3.56 \\
\hline & S.90\%+V.C $10 \%$ & 2.68 & 0.4 & 3.40 & 2.55 & 0.71 & 2.66 \\
\hline & S $80 \%+$ V.C $20 \%$ & 2.91 & 0.4 & 3.89 & 2.93 & 0.83 & 3.56 \\
\hline & S 70\% + V.C30\% & 3.35 & 0.3 & 3.50 & 2.93 & 0.84 & 4.04 \\
\hline L.S.D at 0.05 & & 0.31 & 0.8 & 0.55 & 0.47 & 0.13 & 0.38 \\
\hline
\end{tabular}

N.S Nutrient Solution, V.L Vermin Liquid, C.T Compost Tea

Sand $90 \%$ : commercial compost $10 \%$, sand $80 \%$ : commercial compost $20 \%$, sand $70 \%$ : commercial compost $30 \%$, Sand $90 \%$ : vermicompost $10 \%$, Sand $80 \%$ : vermicompost $20 \%$, Sand $70 \%$ : vermicompost $30 \%$.

L.S.D at 0.05

\section{Conclusion}

The recommendation under the study could be summarized as; using chemical nutrient solution gave the highest results of vegetative, yield and quality characteristics as well as $\mathrm{N}, \mathrm{P}$ and $\mathrm{K}$ contents of cucumber plant. The recommended treatments sand + vermicompost $(80: 20 \mathrm{v} / \mathrm{v})$ combined with chemical nutrient solution. Vermicompost and vermiliquid could be used as sustainable sources of 
substrate amendment and nutrient solution respectively of soilless culture.

\section{References}

AboSedera. F. A., Nadia. S. Shafshak., A. S. Shams., M. A. Abul-Soud. and $M$. H.Mohammed. 2015. The utilize of vermicomposting outputs in substrate culture for producing snap bean. Annals of Agric. Sci., Moshtohor, 53(2), 139-151.

Abou-El-Hassan, S., U. A. El-Behairy, S. M. Selim and A. F. Abou-Hadid. 2008. Effect of compost tea as organic nutrient solution for cantaloupe production grown in nutrient film technique. Egypt. J. Hort. 35. 41-58.

Abul-Soud, M. A. 2005. Studies on producing cucumber by using organic soilless culture systems. Ph.D Thesis, faculty of agriculture, Ain shams university p: 211.

Abul-Soud, M. A., M. S. A. Emam, M. A. A. Abdrabbo and F. A. Hashem. 2014. Sustainable urban Horticulture of sweet pepper via vermicomposting in Summer Season, Journal of Advances in Agriculture 3 (1) 110-122.

Abul-Soud, M., M. K. Hassanein., S.M. Ablmaaty., M. Medany and Abu- A.F Hadid. 2009. Vermiculture and vermicomposting technologies use in sustainable agriculture in Egypt, Egypt. J. Agric. Res., 87 (1).389-403.

Allen, S. E. 1974. Chemical Analysis of Ecological Materials. Black-Well, Oxford, p: 565.

Al-Redhaiman, K. N., M. Z. El-Shinawy and E. M. Abed El-Moniem 2005. Influence of different nutrient sources on the chemical content and yield of lettuce under hydroponic conditions. Egypt. J. Appl. Sci., 20 (1): 255-266.

Amir Khan and FouziaIshaq 2011. Chemical nutrient analysis of different composts (Vermicompost and Pit compost) and their effect on the growth of a vegetative crop Pisumsativum. Asian Journal of Plant Science and Research, 1 (1):116-130.

Angelova V. R., V. I. Akova, N. S. Artinova and K. I. Ivanov. 2013. The Effect of Organic Amendments on Soil Chemical Characteristics. Bulgarian Journal of Agricultural Science, 19 (No 5), 958-971 Agricultural Academy.

Arancon, N.Q, C.A.Edwards, P.Bierman, C. Welch, and J.D. Metzger, 2004. Influences of vermicomposts on field strawberries: 1. effects on growth and yields. Bioresource Technology 93, 145-153.

Arancon, N.Q., C.A.Edwards, A.Babenko, J.Cannon, P.Galvis, and J. Metzger, 2008. Influences of vermicomposts, produced by earthworms and microorganisms from cattle manure, food waste and paper waste, on the germination, growth and flowering of petunias in the greenhouse, Applied Soil Ecology 39, 91-99.
Atiyeh, R. M, N.Q. Arancon, C. A. Edwards and J. D. Metzger. 2000. Influence of earthwormprocessed pig manure on the growth and yield of greenhouse tomatoes. Bioresource Technology, 75, 175-180.

Atiyeh, R. M, S. Lee., C. A. Edwards, N. Q. Arancon and J. D.Metzger, 2002. The influence of humic acids derived from earthwormprocessed organic wastes on plant growth. Bioresource Technology 84:7-14.

Atiyeh, R.M, S. Subler, C.A. Edwards, G. bachman, J.D. Metzger, and W. Shuster. 2000. "Effects of vermicomposts and composts on plan growth in horticultural container media and soil". In Pedobiologia, 44, pp. 579-590.

Atiyeh, R.M., C.A. Edwards, S.Subler, and J. Metzger. 2001. Pig manure vermicompost as a component of a horticultural bedding plant medium: effects on physicochemical properties and plant growth. Bioresource Technology 78, 11-20.

Bachman, G.R and J. D, Metzger. 2007. Physical and chemical characteristics of a commercial potting substrate amended with vermicompost produced from two different manure sources. Hort Technology 17(3), 336-340.

Chapman, H. D. and P. F. Pratt. 1961. Methods of analysis for soil, plant, and water. University of California, Division of Agric Sci.

Cooper, A. J. 1979. The ABC of NFT.Grower Books, London.

Coria-Cayupán, Y.S., M.I.S. De Pintoand M. A. Nazareno, 2009. Variations in bioactive substance contents and crop yields of lettuce (Lactuca sativa L.) cultivated in soils with different fertilization treatments. Journal of Agricultural and Food Chemistry, 57(21), 1012210129.

Domínguez, J. 2004. State of the art and new perspectives on vermicomposting research. In: C.A. Edwards (Ed.). Earthworm Ecology (2nd edition). CRC Press LLC. Pp. 401-424.

El Behairy, U.A .1994. The effect of levels of phosphorus and zinc in the nutrient solution on macro and micronutrients uptake and translocation in cucumber (Cucumis sativus L.) grown by nutrient film technique. PhD Thesis, London Univeristy p: 299.

El-Aidy F. 1990. The effect of planting date, density, variety and shade on production of cucumber under tunnels.Acta Hort. 287: 281-287.

Ernst, G., A. Müller., H. Göhler and C. Emmerling. 2008. $\mathrm{C}$ and $\mathrm{N}$ turnover of fermented residues from biogas plants in soil in the presence of three different earthworm species (Lumbricusterrestris, Aporrectodea longa, Aporrectodeacaliginosa). Soil Biology and Biochemistry. 40:1413-1420.

F. A. O. 1980. Soil and Plant Analysis. Soils Bulletin, 38: 242-250. 
Fernández-Luqueño F., V. Reyes-Varela., C. Martínez-Suárez., G. Salomón- Hernández., J. Yáñez-Meneses., J. M. Ceballos-Ramírez and L. Dendooven. 2010. Effect of different nitrogen sources on plant characteristics and yield of common bean (Phaseolus vulgaris L.). Biores. Technol., 101: 396-403.

George, S., R. S. Giraddi and R. H. Patil. 2007. Utility of Vermiwash for the Management of Thrips and Mites on Chilli (Capsicum annuum L.) Amended with Soil Organics, Karnataka J. Agric. Sci., 20(3): (657-659).

Ghosh C. 2004. Integrated vermi-pisciculture-an alternative option for recycling of solid municipal waste in rural India.Bioresource Technology.; 93:71-75.

Gutierrez-Miceli, F., J. Santiago-Borraz, J. Montes Molina, C.Nafate, Abdu-ArchilaM., M.OlivaLlaven, R.L. Rincon- Rosales, and Dendooven 2007. Vermicompost as a soil supplement to improve growth, yield and fruit quality of tomato (Lycopersicum esculentum).Bioresource Technol. 98(15): 27812786.

Gutiérrez-Miceli, F.A., R. C. García-Gómez., R. Rincón Rosales., M. Abud-Archila., O. L. María Angela., M. J. G. Cruz and L. Dendooven. 2008. Formulation of a liquid fertilizer for sorghum (Sorghum bicolor L.) Moench using vermicompost leachate, Bioresource Technology., 99 (14), 6174-6180.

Haggag, W.M. and M.S. Saber 2007.Suppression of early blight on tomato and purple blight on onion by foliar sprays of aerated and non-aerated compost teas.Journal of Food, Agriculture \& Environment. 5: 302-309.

Hammermeister, A.M., P.R. Warman, E.A. Jeliakova and R.C. Martin, 2004. Nutrient Supply and Lettuce Growth in Response to Vermicomposted and Composted Cattle Manure. J. of Bioresource Technology.

Hashemimajd, K,M.Kalbasi,A.Golchin, and Shariatmadari. H. 2004. Comparison of vermicompost and composts as potting media for growth of tomatoes, Journal of Plant Nutrition, 27: 1107-1123.

Hidalgo, P.R., F.B. Matta and R.L. Harkess. 2006. Physical and chemical properties of substrates containing earthworm castings and effects on marigold growth. Hort Science, 41, 1474-1476.

Inbar, Y., Y Chen and Y. Hadar. 1993. Recycling of cattle manure: The composting process and characterization of maturity. Journal of Environmental Quality, 22: 875-863.

Karuna, Sh, S.Pramod, M.A.Eric, B.W.Kerry, H.Keith and S.B. Andrew 2011. Changes in microbial and nutrient composition associated with rumen content compost incubation, Bioresource Technology, 102, 3848-3854.
Li, L. H. 2009. Practice and experiences in developing the management system for organic tea production.Guangxi Agricultural Sciences. 40: 8, 1098-1100.

MancyA.G. 2013.Evaluation of compost tea as an organic source for plant nutriation.Ph.D. Thesis Fac. Agric. Al-Azhar Univ., Egypt.258.

Manivannan, S., M. Balamurugan., K. Parthasarathi., G. Gunasekaran and L. S. Ranganathan, 2007.Effect of vermicompost on soil fertility and crop productivity of beans (Phaseolus vulgaris), J. Environ. Biol.: 30(2), 275-281.

Monroy F, M. Aira and J. Domínguez. 2009. Reduction of total coli form numbers during vermicomposting is caused by short-term direct effects of earthworms on microorganisms and depends on the dose of application of pig slurry. Science of the Total Environment; 40(7):54115416.

Peyvast, G., J.A. Olfati, S. Madeni and A. Forghani, 2008. Effect of vermicompost on the growth and yield of spinach (Spinaciaoleracea L.). Journal of Food Agriculture and Environment, 6, 110-113.

Rasool, A., T. G. Mousa and H. Behzad. 2009. The effect of sheep-manure vermicompost on quantitative and qualitative properties of cucumber (Cucumis sativus L.) grown in the greenhouse. African Journal of Biotechnology 8: 4953-4957

Raul, I, C. 1996.Measuring physical properties.Rutgers Cooperative Extension.New Jersey Agriculture Experiment Station.New Jersey University.

Roy, S, K. Arunachalam., D. B. Kumar and A. Arunachalam. 2010. Effect of organic amendments of soil on growth and productivity of three common crops viz. Zea mays, Phaseolus vulgaris and Abelmoschusesculentus. Appl.Soil.Ecol. 45:78-84.

Senthilkumar, S., M.V. Sriramachandrasekharan and K. Haripriya, 2004. Effect of vermicompost and fertilizer on the growth and yield of rose. J. Inter academicia, 8: 207-210.

Sharon, D.2006.Recommendations for a Safer Compost Tea. C. F. http: // www. ars. usda .gov/is/pr/2006/060921.htm.

Short, J.C.P., J. Frederickson, and R.M. Morris. 1999. "Evaluation of traditional windrow composting and vermicomposting for the stabilization of was e paper sludge (WPS)." In Diaz Cosin, D.J., Jesus, J.B., and Trogo, D. (Eds), 6th International Symposium on Earthworm Ecology, Vigo, Spain, 1998. Pedobiologia. 1999. 43(6), pp. 735-743.

Singh, N.I and J.S. Chauhan 2009. Response of french bean (Phaseolus vulgaris L.) to organic manures and inorganic fertilizer on growth 
\&yield parameters under irrigated condition Nature and Science; 7(5), ISSN 1545-0740

Singh, R., R.R. Sharma, S. Kumar, R.K. Gupta, and R.T. Patil, 2008. Vermicompost substitution influences growth, physiological disorders, fruit yield and quality of strawberry (Fragaria $x$ ananassa Duch.). Bioresource Technology, 99, 8507-8511.

Sudha, B. and K.K. Kapoor. 2000. "Vermicomposting of crop residues and cattle dung with Eisenia foetida". In Bioresource Technology, 73. pp. 95-98.

Summers, J. 2006.Suggestions for using compost tea in cuttings propagation. Proceedings of the International Plant Propagator,s Society (IPPS). (56): 221-222.

Tejada, M., I. Gomez. T. Hernandez and C. Garcia 2010.Utilization of vermicomposts in soil restoration: effects of soil biological properties, Soil Sci. Soc. Am. J, 74: 525-532.

Tsiang, Y.S.1963. Compost program is vital to nationlist China. Compost Sci., 2: 11-16.

Venugopal, A; M. Chandrasekhar., B. V. Naidu and S. Raju. 2010. Vermicomposting in sericulture using mixed culture of earthworms
(Eudrilluseugineae, Eiseniafoetida and Perionyx excavates) - A review. Agricultural Reviews, 31(2): 150-154.

Wang, D., Q. Shi, X. Wang, M. Wei, J. Hu, J. Liu and F. Yang, 2010.Influence of cow manure vermicompost on the growth, metabolite contents, and antioxidant activities of Chinese cabbage (Brassica campestris ssp. chinensis). Biology and Fertility of Soils, 46, 689-696.

Watanabe, F. S. and S. R. Olsen. 1965. Test of an ascorbic acid method for determining phosphorus in water and $\mathrm{NaHCO}_{3}$ extracts from soils. Soil Sci. Soc. Am. Proc.29: 677-678.

Wilson, G. C. S. 1983. The physic- chemical and physical properties of horticultural substrate.ActaHort No.150: 19-32

Yadav K. D., V. Tare and M. M. Ahammed. 2010. Vermicomposting of source-separated human feces for nutrient recycling. Waste Management; 30:50-56. 


\section{إستخدام المحسنات العضوية لتحسين إنتاجية الخيار المنزرع في بيئة رملية}

فتحى أبو النصر ابو سديرة'ا،سعيد معوض عيد'، لطفى عبدالفتاح عبدالرحمن بدر 1، محمد سعد على إمام²، أحمد محمود حسن حواش2

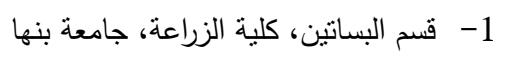

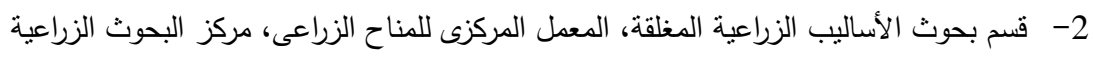

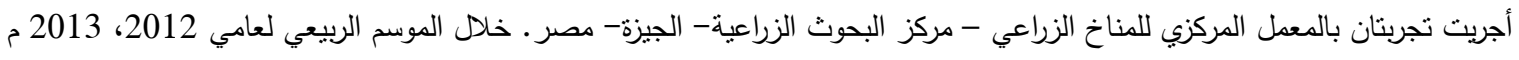

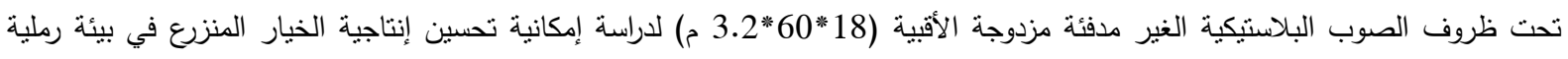

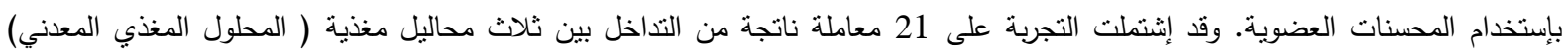

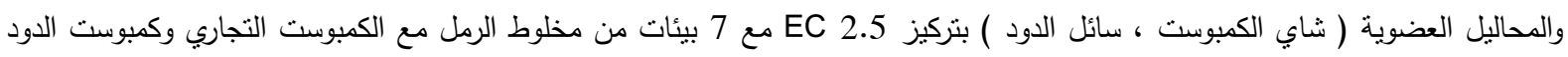

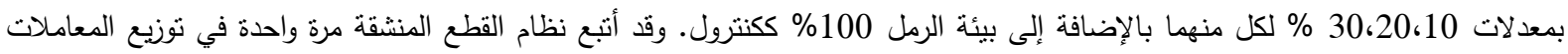

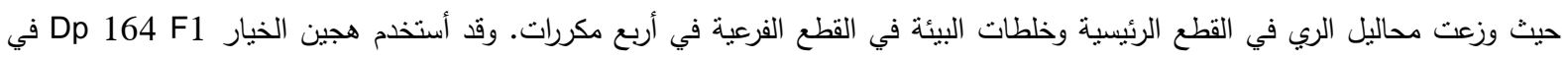

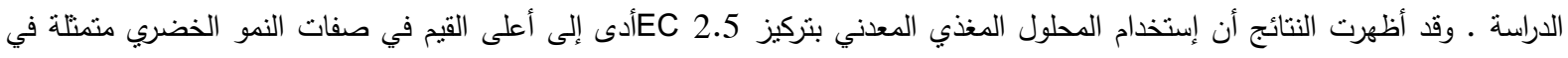

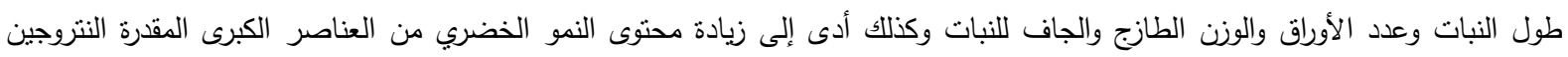

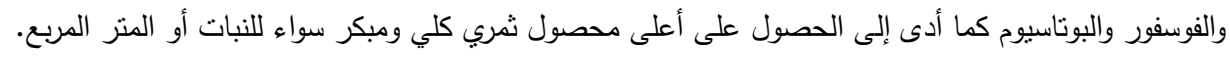

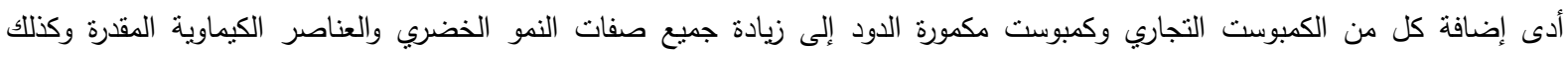

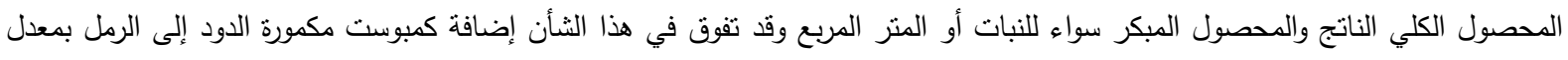

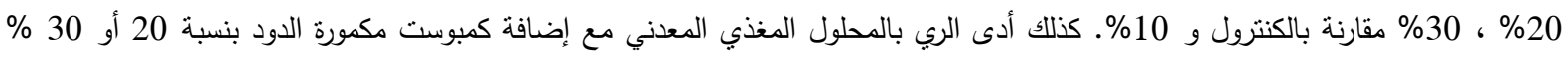
لبيئة الرمل إلى أفضل الننائج. 